\title{
Conceptualizing Portugal as a tourist destination through the textual content of travel brochures
}

\author{
A.S. Guedes, Ph.D. in Tourism ${ }^{\mathrm{a}, *}, \mathrm{M}^{\mathrm{a}}$ Isabel M. Jiménez, Ph.D. in Geography ${ }^{\mathrm{b}, 1}$

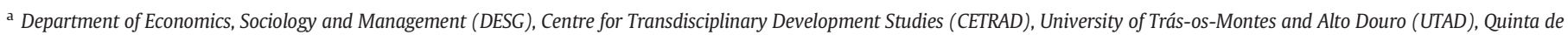 \\ Prados, 5001-801 Vila Real, Portugal \\ b Department of Geography, University of Salamanca, Spain
}

\section{A R T I C L E I N F O}

\section{Article history:}

Received 4 January 2016

Received in revised form 9 August 2016

Accepted 13 August 2016

Available online $\mathrm{xxxx}$

\section{Keywords:}

Textual content

Mental models

Conceptual mapping

Phenomenology

Travel brochures

Portugal

\begin{abstract}
A B S T R A C T
This research adopts phenomenology as a methodological conception that assumes an ontology that coalesces the destination's attributes and the tour operators' perception of the destination. The main focus of this paper concerns the analysis of tourism packages' discourses and its linguistic signs which evoke an understanding and factual (conceptual) knowledge of mainland Portugal as a destination. The results suggest that a new language of tourism is being articulated and transferred to society (main inbound markets) through a network of concepts that bring to fruition a new prototype of mainland Portugal through a wider set of signifying structures. Observed lexical reiterations across all tour operators' discourses suggest that representations of mainland Portugal are implanted with dominant ideological constructs. Despite the overlapping articulations of meaning and interpretation the tour operator's discourse exhibits a richer semantic structure and unveils the implication of places as organizers of space into centres of meaning.
\end{abstract}

(C) 2016 Elsevier Ltd. All rights reserved.

\section{Introduction}

The conceptualization of place through the textual content of brochures (Dann, 1996) consists in connecting the "objective (place)" with the "subjective (tourist experience of that place)" (Ryan, 2000, p. 123). It is therefore a form of scenography built to encourage the anticipation of the tourist experience through "daydreaming and fantasy" (Urry, 1990, p. 3). This is typically engendered through narratives of control (Pan \& Fesenmaier, 2006, p. 827) which are "sustained through a variety of non-tourist practices" (Urry, 1990, p. 3) and "based on signs derived from various discourses of travel and tourism" (Urry, 1990, p. 12; Culler, 1990). These arguments evoke an "institutional/professional gaze" (Hollinshead, 1999, p. 7) that transfers to society a prototype of the destination supported by the "power of institutional truth" (Hollinshead, 1999, p. 12) that conceives "signifying structures that mark and reduce" otherness (Culler, 1990, p. 10). The "tourist place becomes a locus of selected meanings" (Ryan, 2000, p. 121), in this case through the "quiet power of text in tourism" where meaning and perception are "pre-built into and within texts" (Hollinshead, 1999: 18) by "regimes of truth" (Foucault, 1980, p. 131).

\footnotetext{
* Corresponding author at: Rua Jaime Campos, Lote 5, Bloco E, 3. Esq., 5000-436 Vila Real, Portugal.

E-mail addresses: aguedes@utad.pt, alexandreguedes@msn.com (A.S. Guedes), imaji@usal.es (M.I.M. Jiménez).

1 Postal address: Universidad de Salamanca, Departamento de Geografía, Calle Cervantes s.n., 37071 Salamanca, Spain.
}

The exercise of experience control (Pan \& Fesenmaier, 2006) in a pre-trip phase by tour operators that some authors describe as monologues or "one-way 'push' process of mass communication” (Govers, Go, \& Kumar, 2007, p. 978), has undergone profound changes particularly with regard to further fragmentation and transience of the mosaic of signs and symbols that contribute to the creation of an image and imagery of places, namely through tourism (Harvey, 1989, p. 293). The new post-modernizing scenario has been introducing greater complexity and specialization in developing and structuring tourist packages (Sharpley, 2002, p. 316). This change is the result not only of the maturing of the tourist experience that moves further away from standardized and mass tourist experiences in search of a greater diversity of forms of leisure experiences (Urry, 1990, p. 50; Richards, 1997, p. 7) but also of a new economic configuration that has evolved namely towards economies of scope with increased "flexibility in the assembly of package holidays" allowing tour operators to "enter certain niche markets" (Kärcher, 1996, p. 229).

Tourist geographies that have developed as pleasure peripheries (the case of Portugal) as a result of minimizing the diversity (Turner \& Ash, 1975), may reveal in the contemporary discourse of tour operators an adjustment towards greater signaling by increasing the diversity of markers that point to new nodes and places (Guedes \& Jiménez, 2015).

The development of a fuller image of the destination may, via the upsurge of a new "language of tourism" (Dann, 1996, p. 2), which is sustained on a more elaborate and complex semantic structure, provide a wider lens through which anticipation of the tourist experience is constructed (Urry, 1990). 
The acknowledgement of semantic models and structures latent in the tour operator's written discourse will enable to identify those changes and build a proposal of a shared mental model as well as "knowledge representation of a user group or knowledge domain" (Allen as cited by Pan \& Fesenmaier, 2006, p. 812).

The goal of this research is to apprehend the tour operator's conceptual knowledge of mainland Portugal by analyzing their travel brochures' texts from an exploratory perspective, which is typified by the question "What does the text contain?" (Carley \& Palmquist, 1992, p. 607).

\section{Phenomenology as a methodological conception}

The analysis of tour operators' conceptual knowledge of mainland Portugal (object) through their written discourse (package tours) entails a non-dual ontology that coalesces the object (destination) and the subject (tour operator). Hence, it transcends a descriptive observation of the destination, i.e. what is seen, and plunges into the "essence of consciousness" (Husserl, 1983, p. 67) of the tour operator (subject) by examining how the destination is perceived.

Therefore, this study convenes phenomenology, which examines the structure of consciousness, or mental phenomena, which "includes something as object within itself" (Brentano, 1995, p. 68), in our case the destination within the tour operator's consciousness. This "directedness of experience towards objects (and the world) in phenomenology is characterized as the study of intentionality" (Pernecky \& Jamal, 2010, p. 1056). In our research the institutional/professional expert (tour operator) is the first-person structure from whom proceeds the intentionality, which "characterizes consciousness in the pregnant sense" (Husserl, 1983, p. 199), and the perception of the object (destination) or the way it is conceived or thought about.

Package tours' written discourse "includes more than what is expressed in language" which summons the "study of meaning" (Smith, 2013, p. 8) and how the subject (tour operator) experiences a phenomenon, i.e. phenomenology. Yi-Fu Tuan distinctly conveys phenomenology's essence and the importance of the experience (act of consciousness) from the subject's perspective through the following description:

"On a map the two routes are identical and may be shown by the same line with arrows pointing in opposite directions. However, strictly speaking, what is mapped is the route of the car and not that of its human occupant, for whom not only does the scenery change in major ways, depending on whether he is moving in one direction or another, but the route itself acquires different feeling-tones" (1979, p. 401).

Accordingly, the tour operator's written discourse is composed by lexical elements arranged in conformity with syntactical conventions, but what phenomenology seeks to uncover is the structure of consciousness and intentionality of the tour operator through his written discourse by interpreting latent "semantic structures" (Carley \& Palmquist, 1992, p. 603) that evoke an implicit meaning. This can be understood as the object (destination) "as intended to" (Husserl, 1983, p. 244) by the subject (tour operator), what Husserl termed noema. Based on Husseral's basic theory of intentionality, the tour operator's discourse can also be understood as a "medium of intention" (Smith, 2013, p. 292) that seeks to construct the tourist experience in a given space.

Thus, phenomenology illuminates the "intentional or semantic force of ideal meanings" (Smith, 2013, p. 11) which "are shareable by different acts of consciousness" (Smith, 2013, p. 7). Such contention means that the "sharing is made possible through 'intersubjectivity"' (Tuan, $1979,403)$, which is attained when "we come to an understanding with our fellow human being and in common with them posit an Objective spatiotemporal actuality as our factually existent surrounding world to which we ourselves nonetheless belong" (Husserl, 1983, p.
56). In that sense, phenomenology confronts "each individual to examine his own experience, to become subject rather than object of research inquiry, and then reach for common denominators in the experiences of others" (Buttimer, 1976, p. 288). Furthermore, phenomenology proposes a "mode of knowing which recognizes the validity of both modes, but is identical with neither" (objective and subjective) and "...it seeks to encounter, rather than master, the object to be known." (Buttimer, 1976, p. 282). As Li (2000) points out, phenomenological analysis "starts with the content of consciousness (whatever that content may be)" and it "does not concentrate exclusively on either the object or subject of experience, but on the point where being and consciousness meet" (p. 866).

Tour operators' written discourse is accordingly a prolific field for phenomenological analysis by encapsulating and preserving a subconscious knowledge and "stable existence of place" (Tuan, 1979, 411), i.e. the "sense of place" (p. 410).

This underlies the circumstance that understanding of existence and experience "is always an understanding of the world" (Heidegger, 1962, p. 186) which is "governed by the concrete situation of the interpreter" (Pernecky \& Jamal, 2010, p. 1064), in this case the tour operator.

The tour operator's conceptualization of mainland Portugal through written discourse (travel brochures) implies an understanding and interpretation of the "World", which "is the context within which consciousness is revealed" (Buttimer, 1976, p. 281). Therefore, travel brochures capture the tour operator's intelligibility of mainland Portugal as a tourist destination "articulated according to significations; and discourse is this articulation" (Heidegger, 1962, p. 206). In addition, the "way in which discourse gets expressed is language. Language is a totality of words" (Heidegger, 1962, p. 206) and discourse is "existentially language, because that entity whose disclosedness it articulates according to significations, has, as its kind of Being, Being-in-theworld" (p. 206).

Hence, phenomenology, which "signifies primarily a methodological conception" (Heidegger, 1962, p. 50), serves "as a theoretical avenue towards describing or understanding the experiential, and lived existence" (Pernecky \& Jamal, 2010, p. 1056) of tour operators by analyzing their written discourse which is expressed through language, i.e. "the house of being” (Pernecky \& Jamal, 2010, p. 1064).

\section{Words as units of meaning}

The study of written language of tour operators' holiday programs falls into the research framework of cognitive linguistics (dating back to the 1970s) that has had a major incidence on semantics, which is based primarily on the assumption that "words denote concepts, units of meaning" (Croft \& Cruse, 2004, p. 7) which can be compared (e.g. stallion and mare) according to structural semantics. Other approaches to lexical semantics suggest that "concepts can be broken down into semantic features" (e.g. stallion is [equine, male] and mare is [equine, female]) or defined by their "truth conditions" (p. 7), which validate and enable to determine the adequacy of the concept to a particular situation in the world.

The extent and complexity of organizing concepts has expanded research models in cognitive linguistics introducing the notion of context, i.e. "the concept of prototype or paradigm case, the notion of «frame» or "schema» (...) and the notion that sometimes goes by the name of "semantic memory"” (Fillmore, 1976, p. 23).

According to Fillmore the concept of meaning materializes in numerous different contexts and therefore the knowledge of word meanings involves knowledge of prototypes, i.e. the notion of "frame» (Fillmore, 1976, p. 24). Thus "words and constructions evoke an understanding, or more specifically a frame" (Croft \& Cruse, 2004, p. 8). Frames can be described as "any of the many organized packages of knowledge, beliefs, and patterns of practice that shape and allow humans to make sense of their experiences." (Fillmore \& Baker, 2009, p. 314). Concurring with Fillmore and Baker (2009) the "frames we 
invoke are based on knowledge we have, not so much about the words, as about the phenomena and their association with cultural values" (p. 317). The meaning of a text is "vastly underdetermined" (Fillmore \& Baker, 2009, p. 316) by its linguistic forms (words, fixed phrases, grammatical patterns) alone. Thus, a given linguistic sign (e.g. a word) "evokes the (linguistically anchored) frame" (Fillmore \& Baker, 2009, p. 316), i.e. the cognitive structure, which largely determines the process (and the result) of interpreting by giving a specification of the word's meaning that includes its relation to the world (Johnson-Laird, 1980, p. 89).

Furthermore, the "process of communication can be seen as involving one person saying something that will induce another person to change his model of the world" (Fillmore, 1976, p. 26) which supports the argument that language of tourism and tour operators' commercial discourse is constructed to induce the tourist gaze towards a concrete destination (Salim, Ibrahim, \& Hassan, 2012, p. 136). Hence, a central characteristic of discourse is "reference and referential continuity" (Johnson-Laird, 1980, p. 106). "The referents of expressions ${ }^{2}$ depend in part on the context" which consists of mental models.

According to Johnson-Laird (1983), mental models are "constructed from tokens arranged in a particular structure to represent a state of affairs" (p. 398) enabling "individuals to make inferences and predictions, to understand phenomena, to decide what action to take, and to control its execution, and above all to experience events by proxy". Models "relate words to the world by way of conception and perception" (p. 397). If the "perception of the world is model-based, then the discourse about the world must be model-based" ( p. 407). This circular relationship synthesizes/resumes the importance of the concept of semantic mental model for this research, which focuses on the "discourse about the world" from an institutional/professional perspective, i.e. the tour operator's mental model supporting his discourse.

Mental models can accordingly be regarded as triggers of awareness and perception of objects by representing information analogically (Ellis \& Cohen, 2008, p. 166) and a central concept in understanding how the destination (the objective) and the experience (the subjective) are construed.

Cognitive and conceptual mapping is applied in this research to value and grasp the tour operator's declarative/conceptual knowledge of mainland Portugal (Solaz-Portolés \& López, 2008). Cognitive and conceptual mapping provide valid information about the conceptual framework to measure the structure of declarative knowledge (or conceptual) (Ruiz-Primo \& Shavelson as cited in Solaz-Portolés \& López, 2008, p. 107). Thus, according to Carley and Palmquist (1992) it is the most effective way to explore the "nature of shared knowledge in social groups (...) and the results can be used in relatively large numbers of individuals". As well the "results can be compared to each other (...) or to idealized representations of the content structure of a given domain" (Carley \& Palmquist, 1992, p. 605). Given that frames (cognitive structure) constitute an evocation of words, being defined on semantic grounds, independently of language, most of them are comparable across languages (Fillmore \& Baker, 2009, p. 337). Additionally, cognitive (conceptual) mapping includes content analysis since it can bestow information about the occurrence of words or phrases in a given text (Carley \& Palmquist, 1992, p. 606).

Thus, the textual content of travel brochures represents a capsule of the tour operator's factual knowledge (declarative) and also a repository of semantic substance that enables the recognition and extraction of latent mental models.

Based on these assumptions, the main focus of this research concerns the analysis of the tour operators' written discourse and its linguistic signs which evoke an understanding and factual (conceptual) knowledge of mainland Portugal as a destination. Ultimately, it is our intention to extrapolate a general conceptual model that condenses a

\footnotetext{
2 E.g. the thing that the word stands for.
}

nucleus of signs whose structure itself "provides an ontological clue for "characterizing"' and indicating (a "kind of 'referring"') (Heidegger, 1962, p. 108) the destination from the first person's structure perspective, i.e. the tour operator.

\section{Methodology and conceptual model}

On the basis of this discussion, this research adopts phenomenology as a "methodological conception" (Heidegger, 1962, p. 50) that attempts to "transcend the dualism between 'subjective' and 'objective' modes of understanding experience" (Buttimer, 1976, p. 281). According to Heidegger (1962) phenomenology "neither designates the object of its researches, nor characterizes the subject-matter thus comprised. The word merely informs us of the 'how' with which 'what' is to be treated in this science" (p. 59). Hence phenomenology allows a descriptive observation of "what" is seen by the subject (tour operator) but also the "way" it is perceived.

The tour operator's understanding and interpretation is underlined by discourse, i.e. "Discourse is the Articulation of intelligibility" (Heidegger, 1962, p. 203-204) and meaning, which is encapsulated in travel brochures. Therefore, tour operators constitute formal sources (Goodall, 1990) that "help to construct and develop our gaze as tourists" (Urry, 1990, p. 1) through their interpretation of the destination which is preserved in travel brochures as relevant "content of consciousness" (Li, 2000, p. 266) that can be subject to phenomenological analysis.

As "a disciplinary field in philosophy" (Smith, 2013, p. 1), phenomenology "has been appropriated to provide methodological guidance in applied research" (Pernecky \& Jamal, 2010, p. 1056) and therefore serving as a "preamble to, rather than the operational formula for, research methods" (Buttimer, 1976, p. 291). It is thus "a research perspective to study experience in the humanistic and social science disciplines" (Pernecky \& Jamal, 2010, p. 1056) and a "methodological conception" (Heidegger, 1962, p. 50) that steers qualitative research, namely in tourism. According to Ryan (2000), qualitative research "does not exist separate from empiricism, but extends empiricism towards individuality" (p. 122). This assertion subsequently applies to our case which attempts to apprehend the tour operator's "conscious experience as experienced" (Smith, 2013, p. 1) which is uttered through language (travel brochure's written discourse); what Heidegger defined as "a totality of words" (1962, p. 204).

Hence, this assignment undertook the analysis of tourism packages' discourses of each one of the six most relevant inbound markets (UK, Germany, Spain, France, Italy and the Netherlands) for mainland Portugal and identified the most frequent key words that constitute "induced image variables" (Stepchenkova \& Morrison, 2006, p. 944).

This research was based on a sample frame provided by Turismo de Portugal (the Portuguese central public authority responsible for promotion, enhancement and sustainability of tourism activities) containing 986 tour operators from six relevant countries of origin for Portugal's inbound markets. A non-random sample ${ }^{3}$ was drawn cutting down the initial list to 103 tour operators that were selected as a result of content analysis. From this sample a total of 330 package tours provided a source for data extraction (Table 1).

The selection of tour operators was based on package tours containing textual content which displayed a descriptive affluence allowing the attainment of semantic analysis and ultimately enabling the extraction of mental models and "signifying structures" (Culler, 1990, p. 10) that configure the prototype of the destination and the tour operator's declarative knowledge (or conceptual) on mainland Portugal.

Given that the "totality-of-significations of intelligibility is put into words" (Heidegger, 1962, p. 203) and the written discourse is the articulation of the subject's (tour operator) intelligibility of the object

\footnotetext{
${ }^{3}$ Non-probability approach is more suitable for qualitative research in which the focus is often to understand "complex psychosocial issues" and "answering humanistic "why?» and «how?» questions" (Marshall, 1996, p. 522).
} 
Table 1

Sample of tour operators analyzed.

\begin{tabular}{llllll}
\hline $\begin{array}{l}\text { Inbound } \\
\text { markets }\end{array}$ & $\begin{array}{l}\text { Sample } \\
\text { Frame (tour } \\
\text { operators) }\end{array}$ & $\begin{array}{l}\text { Sample } \\
\text { (tour } \\
\text { operators) }\end{array}$ & $\begin{array}{l}\text { Source for } \\
\text { data extraction } \\
\text { (Package tours) } \\
(*)\end{array}$ & $\%$ \\
\hline Italy & 123 & 28 & $23 \%$ & 125 & $38 \%$ \\
Germany & 312 & 24 & $8 \%$ & 57 & $17 \%$ \\
Spain & 126 & 13 & $10 \%$ & 57 & $17 \%$ \\
France & 141 & 18 & $13 \%$ & 48 & $15 \%$ \\
UK & 213 & 14 & $7 \%$ & 30 & $9 \%$ \\
The Netherlands & 71 & 6 & $8 \%$ & 13 & $4 \%$ \\
Total & 986 & 103 & $10 \%$ & 330 & $100 \%$ \\
\hline
\end{tabular}

(mainland Portugal) "according to significations" (Heidegger, 1962, p. 206), the selection of package tours was grounded on the evidence of textual content that conveyed "meaning", i.e. that "which can be articulated in interpretation" (Heidegger, 1962, p. 204).

The following excerpt exemplifies this study's discourse archetype which constitutes our source of analysis of the tour operator's perception of the destination (the object) and his "sense of place" by applying a "moral and aesthetic discernment to sites and locations" (Tuan, 1979, p. 410):

"Alcobaça, Batalha, Tomar. Drive south to two extraordinary monasteries of the greatest beauty and historical significance. Alcobaça, founded in 1153, is a building of breathtaking Gothic purity. Nearby Batalha, built by order of King João I, mixes French Gothic and Manueline in an intoxicating display. The drive east becomes increasingly rural. First of two nights in the small town of Tomar."

[(Martin Randall Travel, 2013, p. 170)]
The analysis of the tour operator's written discourse combined the assistance of neural software, Catpac II, which allowed to bring together qualitative research approach with quantitative and statistical probing, applied in previous studies on destination image and mental models (Choi, Lehto, \& Morrison, 2007; Govers et al., 2007; Pan \& Fesenmaier, 2006; Stepchenkova \& Morrison, 2006). Catpac II is a neural network program designed to read and assist interpretation by apprehending the interrelationships between words and phrases in the text, and identifies underlying concepts (Woelfel, 1998).

To analyze the textual content all travel programs were manually processed or transformed to Microsoft Word format and sequentially converted into ASCII text (Fig. 1). All texts were purged from a set of stop words (e.g. "when", "how") considered "not content-bearing words" (Woelfel, 1998, p. 31). This procedure was simplified by running an exclusion file that included the words to be omitted from the analysis.

All six inbound markets files contained a total of 76,280 words being shorten down to a total of 9976 words for analysis by applying the exclusion file. Catpac II was queried to identify no more than 18 unique words used for semantic analysis (Table 2).

Each inbound market text was run on Catpac II, generating a descriptive statistical output of the words' occurrence and a dendogram as a result of a hierarchical cluster analysis (Ward's minimum variance method) which explains the relationship between the most common concepts, enabling semantic network generation and analysis of each inbound market. Additionally, to enable a more precise and detailed analysis, coordinate information was extracted from the dendogram window and placed in a .crd file for further generation of perceptual maps using a bundled software, ThoughtView.

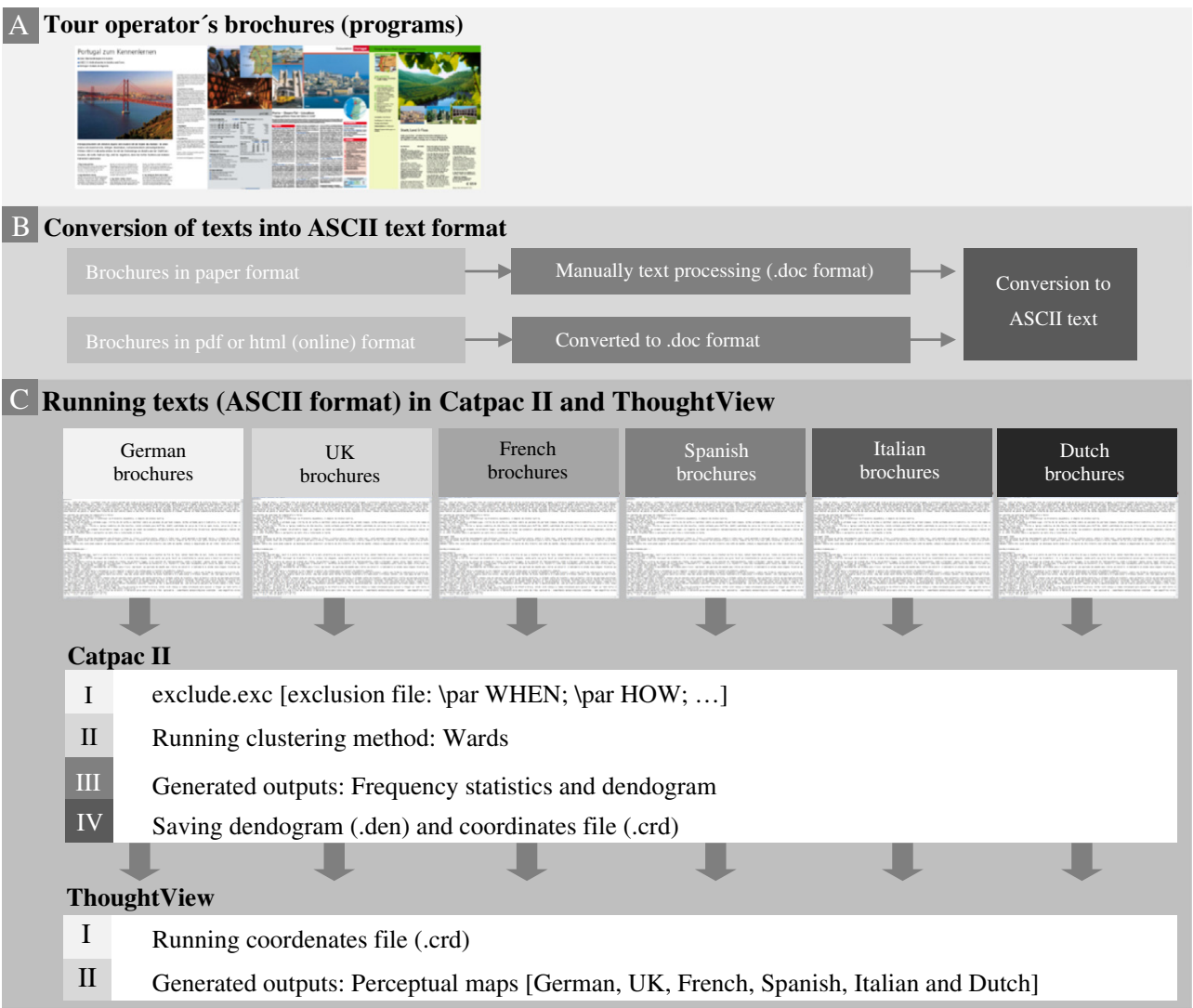

Fig. 1. Methodology and extraction of semantic mental models. 
Table 2

Analysis textual content

\begin{tabular}{|c|c|c|c|c|c|c|c|}
\hline & Germany file & UK file & French file & Spanish file & Italian file & Dutch file & Total \\
\hline Total words $(\mathrm{t})$ & 12,605 & 9896 & 14,018 & 16,854 & 19,608 & 3299 & 76,280 \\
\hline Words analyzed after using exclude file (w) & 1598 & 1113 & 1690 & 1717 & 3420 & 438 & 9976 \\
\hline$\%$ of words analyzed $(\mathrm{w} / \mathrm{t})$ & $13 \%$ & $11 \%$ & $12 \%$ & $10 \%$ & $17 \%$ & $13 \%$ & $13 \%$ \\
\hline Total unique words & 18 & 18 & 18 & 18 & 18 & 18 & - \\
\hline Total episodes & 1544 & 1107 & 1331 & 1634 & 3414 & 432 & 9462 \\
\hline Total lines & 3413 & 1769 & 2847 & 4719 & 6537 & 521 & 19,806 \\
\hline
\end{tabular}

Ultimately, a synthesis of all results and semantic structures is carried out and a prototype of a shared mental model is proposed.

\section{Results and discussion}

\subsection{The German market mental model}

The words "Lisbon" and "Porto" hold the highest frequency of occurrences (Table 3) on German tour operators' written discourse which exhibits the contextualizing relevance of the objective (place) when conceptualizing place. Lisbon embodies a strategic gateway of entryexit to mainland Portugal with "transitional purposes" (Guedes \& Jiménez, 2015, p. 111) a role it shares with "Porto", also considered a "strategic hub with a transience and intermediation purpose" (Guedes \& Jiménez, 2015, p. 112).

Furthermore, the words "Évora" and "Sintra", which appear in 6th and 7th position on the list of frequencies, again expose the importance of spatial referents when devising a narrative which clearly aims to control the reader's construal of the destination. 8 out of 18 unique words identify specific spatial nodes within the destination (other spatial units include "Cascais", "Coimbra”, "Faro" and "Fátima”).

The written discourse seems to be shaped by regional configurations/frames that remit to a concept of natural area, "characterized both by a physical individuality and by the cultural characteristics of the people who live in it" (Zorbaugh as cited by Timms, 1971, p. 6) evoking thematic drawers that enclose experiential opportunities. The words "Algarve" (Portuguese sea and sand destination and the most southern region), "Douro" (World Heritage, wine-growing region namely Port Wine) and "Alentejo" (comprising one UNESCO asset, wine producer and heritage destination) seem to acknowledge this model.

In addition, a heritage semantic taxonomy composed by words/concepts that include cultural and natural morphologies seems to provide

Table 3

Output frequencies - German programming.

\begin{tabular}{lll}
\hline Descending frequency list & & \\
\hline Word & Freq & Pcnt $^{\mathrm{a}}$ \\
\hline LISBON & 370 & 23,2 \\
PORTO & 236 & 14,8 \\
CASTLE & 95 & 5,9 \\
ALGARVE & 82 & 5,1 \\
RIVER & 75 & 4,7 \\
ÉVORA & 75 & 4,7 \\
SINTRA & 74 & 4,6 \\
CASCAIS & 62 & 3,9 \\
TEJO & 61 & 3,8 \\
COAST & 60 & 3,8 \\
TOUR & 60 & 3,8 \\
COIMBRA & 55 & 3,4 \\
CHURCH & 51 & 3,2 \\
DOURO & 50 & 3,1 \\
BEACH & 49 & 3,1 \\
FARO & 48 & 3,0 \\
FÁTIMA & 48 & 3,0 \\
ALENTEJO & 47 & 2,9 \\
\hline
\end{tabular}

\footnotetext{
a "Percentage of time that particular word was used in the
} text" (Woelfel, 1998, p. 37) figurative markers that set up the stage for daydreaming and anticipation of the tourist experience. These include the word "Castle" which boasts the 3rd highest number of absolute frequencies, possessing both cultural and allegorical meaning (e.g. ancient and Medieval), "Church", the 13th highest word occurrence, evoking religion and architecture, "River", the 5th most cited word educing two important Portuguese rivers (Douro and Tagus), "Coast" as a geographical reference imbued with metaphorical meaning along with the word "Beach", both suggesting a coastal nation in southwestern Europe.

The tour operator's written discourse exhibits further articulations of his intelligibility of the destination by adding the word "Tour", which refers to an experiential and subjective concept (Pan \& Fesenmaier, 2006), suggesting a combination of a set of spatial units and resources, as well as evoking gaze and contemplation archetypes. The word "Tour" seems to be affiliated to a set of spatial referents, namely "Porto" and "Lisbon", which could explain and interpret these nodes' condition as portals that provide access to semi-peripheral and peripheral areas (Guedes \& Jiménez, 2015). Furthermore, the perceptual map exhibits, in the same quadrant (IV) (Fig. 2) nodes that are located along spokes, i.e. "Sintra” and "Cascais", around the hub Lisbon, suggesting a hub-and-spoke model (concept used in transport networks) (Rodrigue, Comtois, \& Slack, 2006) which is fitting with the experiential dimension evoked by the word "Tour".

The referred latent concepts entail further relations with the aforementioned words which are projected in the perceptual map, allowing the observation of close associations which also evoke understanding of the destination. This is particularly evident in cases that combine heritage features with particular spatial referents. The words "Coast" and "Beach" cluster with words that identify specific regional hotspots, namely the "Algarve" and the "Alentejo". The word "Faro", which is also in the vicinity of the word "Algarve", its regional administrative boundary, seems to reflect its appendant and functional role as a gateway to the region (Algarve) due to its international airport.

Also the words "Fátima" and "Coimbra" appear isolated in different quadrants, seemingly representing a dichotomous relationship which can outcome from these spatial units' singularities. On the one hand, "Fátima" exhibits a strong association with a religious circumstance and history and "Coimbra" is tied to the academic aura and University legacy, which dates back to the 13th century. This apparent disjunction in the perceptual map conceals their proximity in terms of spatial sequence planning by tour operators, which can be observed in many occasions.

\subsection{The UK mental model}

The UK market reveals a tendency towards a particular regionalized narrative, which is consistently exhibited through the convergence of the discourse components around the word "Douro" (region) followed by the word "Port" (meaning Port wine) (Table 4). The region (Douro) and its main produce are consistently tied, leading us to an "extensional interpretation" (van Dijk, 1985, p. 104) and understanding (notion of frame) of the Portuguese and English historical affinity condensed around Port wine's commercial saga.

The perceptual map (Fig. 3) displays other specific regional layers that seem to cluster around the word "Douro", what seems to be an attempt of the tour operator to exert his "sense of place", putting forth this 


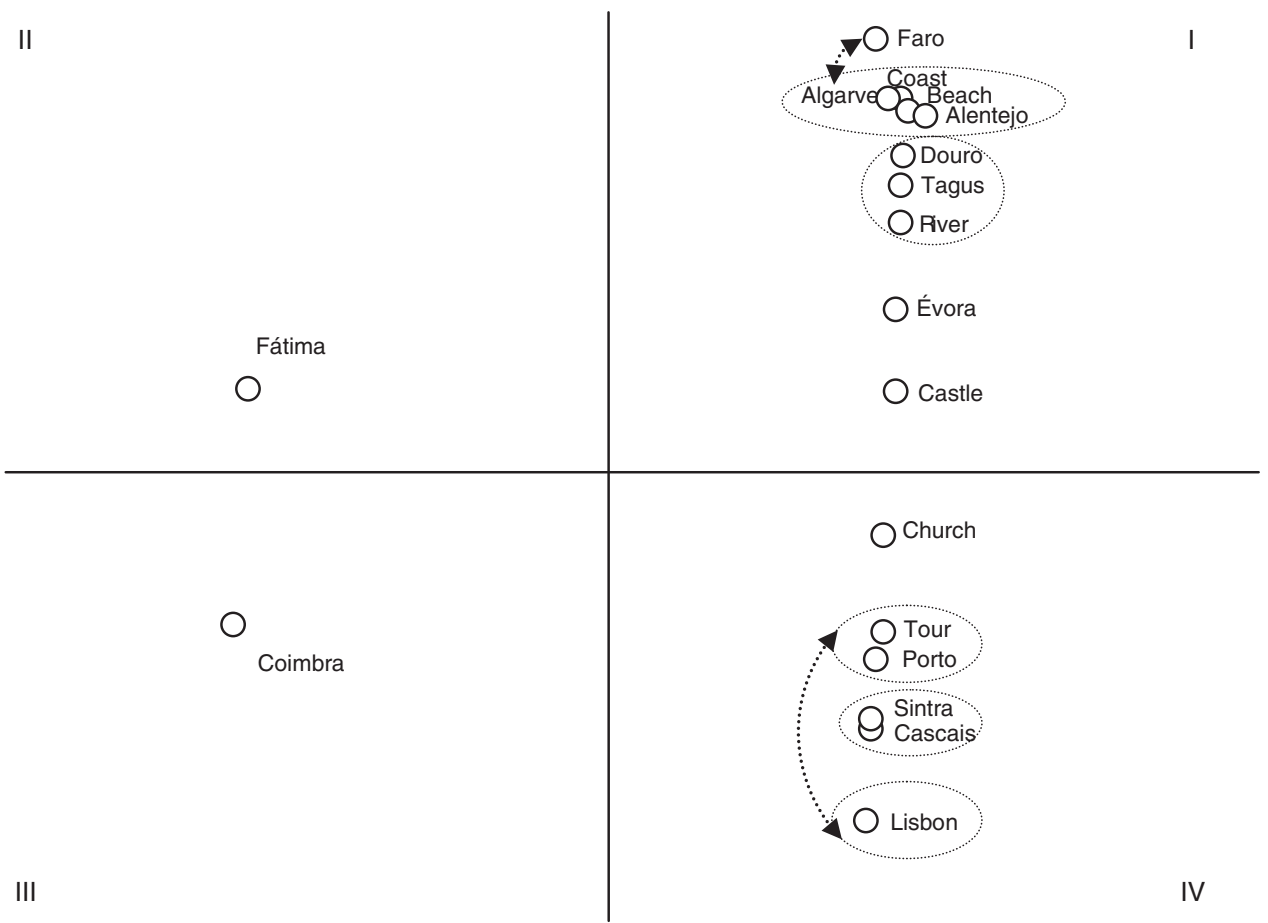

Fig. 2. Semantic model of German programming.

region's genius loci and its aesthetic pattern. On this matter, the tour operator's cognitive structure draws upon specific lexicon that "belong together" (Croft \& Cruse, 2004, p. 7): “Quinta”, "River”, "Valley", "Wine", "Port" and "Train".

The word "Tour" follows in 3rd place, representing a paradigm of interaction with the terroir (wine growing region) and conveying an archetype of territorial immersion that is fitting with the dominant spatial morphology uttered in the written speech. Moreover, the relevance of the Douro scene is amplified by associating the word "River", rendering a natural dimension to the destination. The semantic map adds the word "Valley" alluding to the Douro valley and additionally the word "Quinta" which constitutes a unique structural element of the wine region landscape. It holds a unifying territorial purpose and scenic significance, remitting to a dimension of contemplation (gaze), namely through the combination of the word "Sightseeing", which is ranked in 8th place of all unique words.

Table 4

Output frequencies - UK programming.

\begin{tabular}{lll}
\hline Descending frequency list & & \\
\hline Word & Freq & Pcnt \\
\hline DOURO & 136 & 12,2 \\
PORT & 124 & 11,1 \\
TOUR & 107 & 9,6 \\
RIVER & 101 & 9,1 \\
WINE & 96 & 8,6 \\
LISBON & 81 & 7,3 \\
DRIVE & 53 & 4,8 \\
SIGHTSEEING & 53 & 4,8 \\
CATHEDRAL & 45 & 4,0 \\
CHURCH & 44 & 4,0 \\
PALACE & 38 & 3,4 \\
VALLEY & 38 & 3,4 \\
PORTO & 37 & 3,3 \\
COIMBRA & 33 & 3,0 \\
CASTLE & 32 & 2,9 \\
QUINTA & 32 & 2,9 \\
TRAIN & 32 & 2,9 \\
MEDIEVAL & 31 & 2,8
\end{tabular}

To conclude the conceptualization of the Douro region, the word "Train" (the Douro rail) surfaces which is also related with a gaze and recreation dimension that, again, is validated by its' seemingly relation in the perceptual map with the word "Sightseeing".

Again "Lisbon" and "Porto", although ranked in 6th and 13th place, which apparently suggests a tributary significance in the UK programming, still retain a functional role as transient hubs, which is suggested by their inclusion in the same quadrant as the word "Tour", which implies the combination of different spatial nodes.

"Coimbra" is the 14th most cited spatial unit, disclosing a distinctive factor relatively to "Lisbon" and "Porto", which is suggested by its isolated position in Quadrant IV (Fig. 3). This could imply a univocal and unambiguous meaning, i.e. the University (classified by UNESCO), which is also a common feature in the German semantic mental model.

The UK words frequency list includes similarly a heritage semantic taxonomy which combines several architectural morphologies namely "Cathedral", "Church", "Palace" and "Castle", bestowing cultural and historical texture to the destination's representation as well as authenticity which is evoked through an historical token supported by the word "Medieval" that seems to be coupled with "Porto". Furthermore, the word "Drive", which represents the 7th most cited word, holds a spatial, physical and experiential scope associated with a particular context, considering its coalition to the word "Castle".

Furthermore, the conceptualization of place is achieved by articulating the objective, i.e. spatial and resource referents, with the subjective, i.e. "tourist experience of that place" (Ryan, 2000, p. 123), which in this case is devised by insetting simulating experiential layers in separate quadrants comprised by the words "Tour", "Drive" and "Sightseeing".

\subsection{The French mental model}

The French semantic mental model exhibits a total of 7 unique words which recognize spatial units. The most cited word is "Porto" followed by "Lisbon" (Table 5). These two semantic components again embody strategic nodes of entry-exit and transience to and within the destination. 


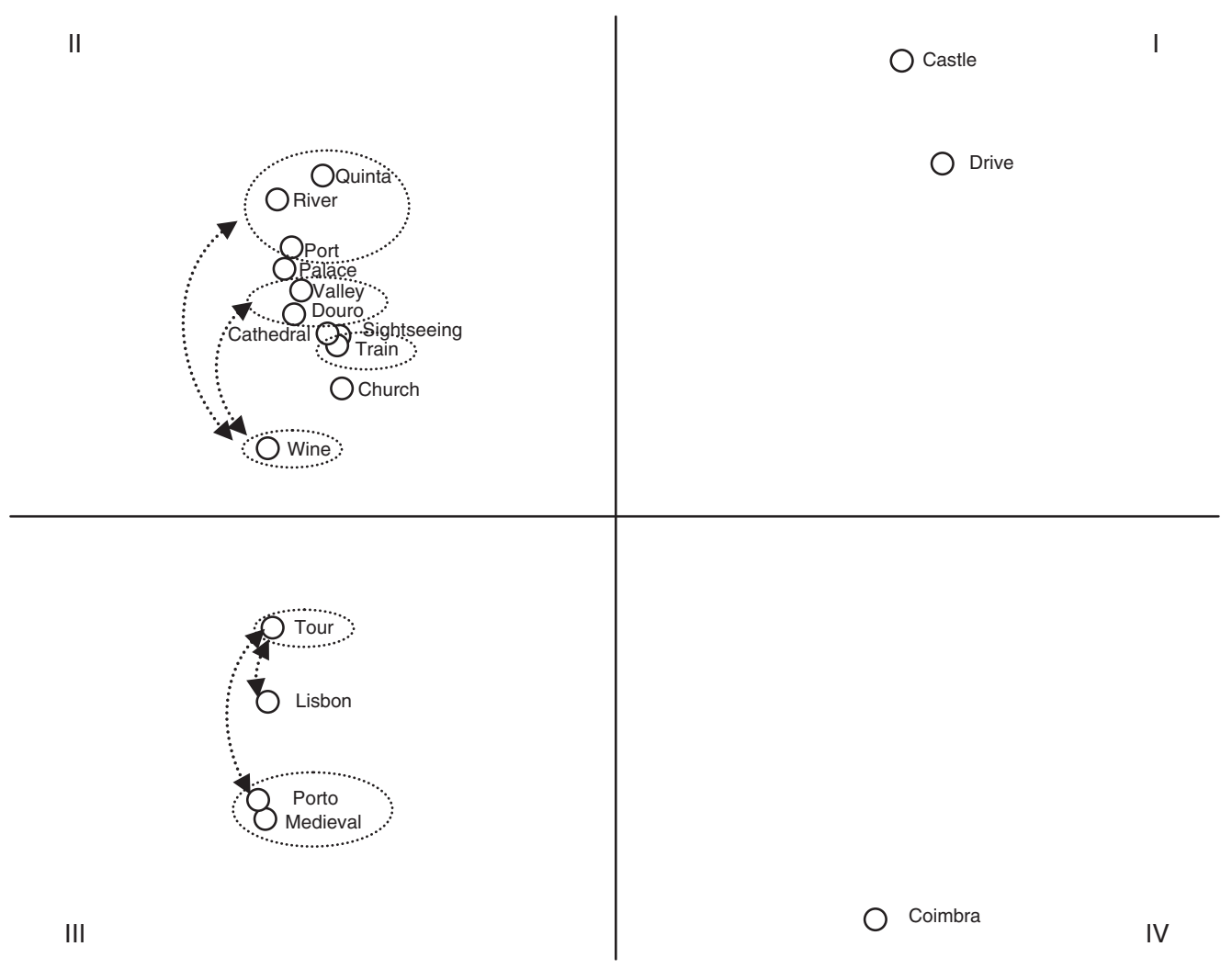

Fig. 3. Semantic model of UK programming.

Still, these two spatial units exhibit different positions ("Porto" in Quadrant I and "Lisbon" in Quadrant IV) in the perceptual map (Fig. 4), which may suggest particular geographic and cultural contexts that provide distinctive spatial and geographical overlaps (i.e. "Porto" North and "Lisbon" - South).

Again the importance of the word "Douro" is disclosed, figuring as the 5th most common word, assuming a double meaning/significance, i.e. a regional destination (wine and river tourism) and a spatial corridor that links "Porto" to peripheral nodes such as "Régua", "allowing a regional interchange of tourism flows" (Guedes \& Jiménez, 2015, p. 112). This dimension can be amplified by the word "Tour", which evokes an experiential concept as well as a transient meaning by

Table 5

Output frequencies - French programming.

\begin{tabular}{lll}
\hline Descending frequency list & & \\
\hline Word & Freq & Pcnt \\
\hline PORTO & 363 & 21,5 \\
LISBON & 288 & 17,0 \\
PALACE & 108 & 6,4 \\
CATHEDRAL & 91 & 5,4 \\
DOURO & 86 & 5,1 \\
MONASTERY & 82 & 4,9 \\
TOUR & 75 & 4,4 \\
MUSEUM & 72 & 4,3 \\
COIMBRA & 59 & 3,5 \\
CRUISE & 58 & 3,4 \\
RÉGUA & 56 & 3,3 \\
BRAGA & 55 & 3,3 \\
SINTRA & 53 & 3,1 \\
AZULEJOS & 52 & 3,1 \\
BOAT & 52 & 3,1 \\
CASTLE & 50 & 3,0 \\
BARROQUE & 45 & 2,7 \\
FÁTIMA & 45 & 2,7 \\
\hline
\end{tabular}

suggesting a circulation model supported by a cluster of spatial units (i.e. "Porto”, “Braga”, “Régua”, “Coimbra” and "Fátima”).

The perceptual map discloses further specific levels of tourist immersion along with an experiential value, namely by quoting the word "Boat" which constitutes a motivational marker that has as a reference the river "Douro", both evoking the river's navigability capacity.

An additional evidence of tour operators' method of conceptualizing place can be extrapolated from the implied relationship between particular cultural morphologies and distinctive spatial units. This can be observed through the collage of a single qualifying and artistic style, i.e. "Baroque", to particular spatial elements, namely "Braga", "Coimbra" and "Douro". As well, the last quadrant suggests a relationship between the word "Palace" and specific urban and semi-urban landscapes: "Lisbon" and "Sintra". These associations imply the significance of cultural content of spaces, which act as markers (Culler, 1981; MacCannell, 1976). Again, these two spatial nodes exhibit a hub-andspoke configuration. Furthermore, the first quadrant exhibits the word "Azulejos" ${ }^{4}$ which evokes a distinct Portuguese artistic and architectural feature, assigning an idiosyncratic and subjective representation of space through culture. Additionally, the word/concept "Fátima", as discerned in the German semantic model, is feasibly alluding to a religious dominion.

As observed in the UK semantic model, a specific group of architectural morphologies, i.e. "Castle", "Palace", "Cathedral" and "Monastery" are listed key words, although in the following model they are clustered in the same quadrant with the words "Cruises" and "Museums", which evoke services. The latent association of both architectural morphologies and services concepts in the same quadrant could suggest a crosswise spatial correlation (e.g. "Porto - Museum", “Lisbon - Museum"). 


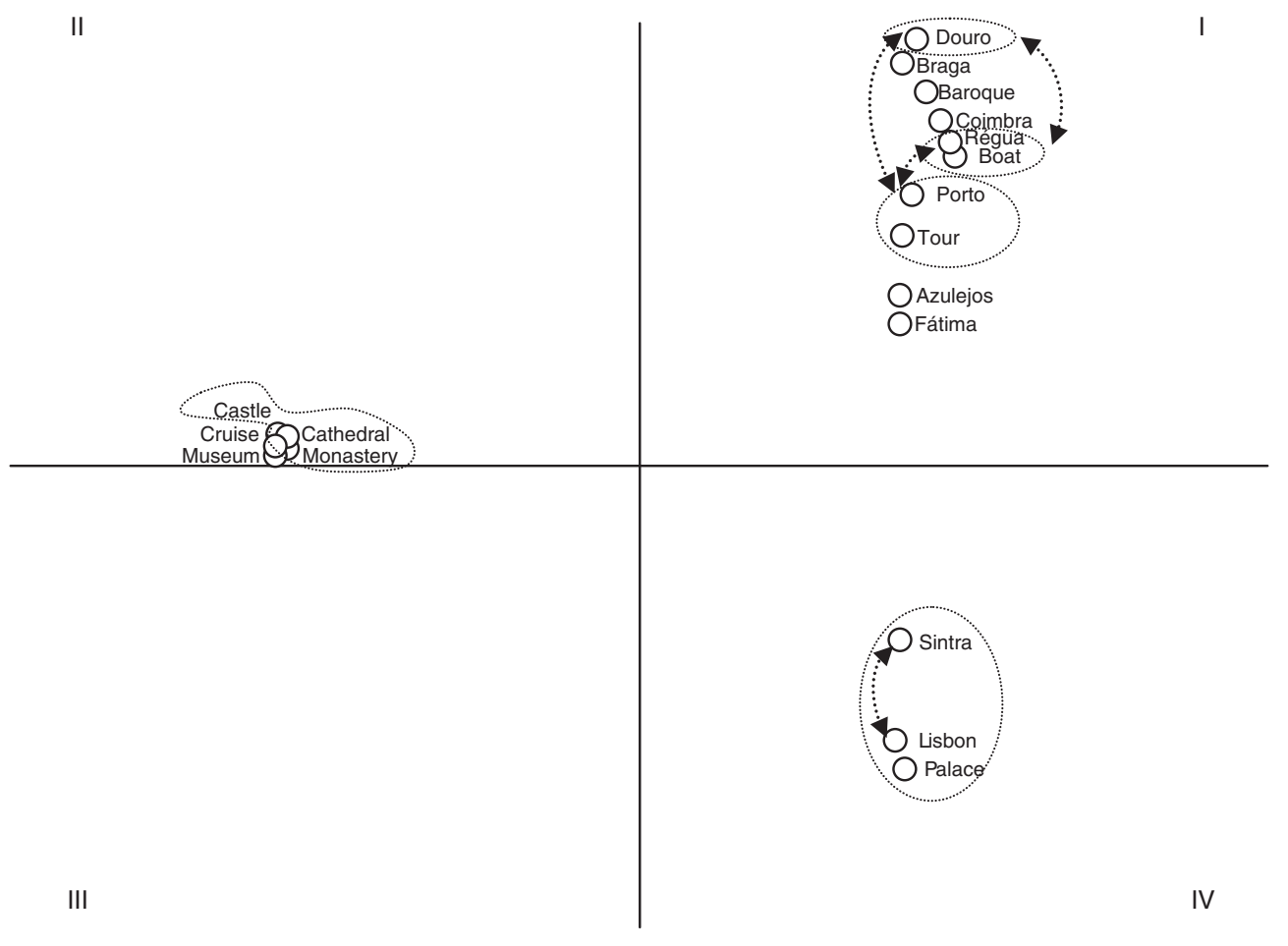

Fig. 4. Semantic model of French programming.

\subsection{The Spanish mental model}

The Spanish written content (Table 6) exhibits again the predominance of the words "Lisbon" and "Porto", which stand out as cultural and infrastructural hubs that enable important functional links with semi-peripheral and peripheral areas in specific contexts, as it is shown by their position in different quadrants of the perceptual map (Fig. 5).

Similar to the French and German models, the list of unique words shows a broader spatial representation displaying 8 municipal (and sub-municipal) administrative units.

Noteworthy is a core of words, most of them exhibited in previous semantic models that hold figurative character due to their explicit

Table 6

Output frequencies - Spanish programming.

\begin{tabular}{lll}
\hline Descending frequency list & & \\
\hline Word & Freq & Pcnt \\
\hline LISBON & 353 & 20,6 \\
PORTO & 131 & 7,6 \\
PALACE & 106 & 6,2 \\
SINTRA & 95 & 5,5 \\
ROUTE & 94 & 5,5 \\
MONASTERY & 92 & 5,4 \\
COAST & 91 & 5,3 \\
CATHEDRAL & 87 & 5,1 \\
CASCAIS & 81 & 4,7 \\
PLAZA & 80 & 4,7 \\
FÁTIMA & 77 & 4,5 \\
HERITAGE & 69 & 4,0 \\
CASTLE & 62 & 3,6 \\
COIMBRA & 62 & 3,6 \\
ESTORIL & 62 & 3,6 \\
TOWER & 60 & 3,5 \\
LANDSCAPES & 58 & 3,4 \\
ÉVORA & 57 & 3,3 \\
\hline
\end{tabular}

association to an array of architectural morphologies: "Palace”, "Monastery", "Cathedral", "Tower", "Castle" as well as the concept of "Plaza" which remits to an architectural archetype imbued with social significance in the Spanish culture.

In addition to the cultural heritage representation which holds an allegorical and figurative extent, the list of unique words includes the concept of "Heritage" which is a generalized and expanded reference to the previous architectural markers, conceptually aggregating all cultural assets.

The words "Coast" and "Landscape" are also part of the concepts that feature the destination's heritage and scenery portrayed in the semantic model (Fig. 5). These contextualize the destination's natural environment and act as spatial referents. Likewise, the concept of "Landscape" suggests a contemplative meaning and bestows a cultural metaphor to the written portrayal of the destination due to its association with cultural features, i.e. "Monastery", "Tower" and "Coimbra" (UNESCO site).

The word "Route" also configures a distinctive character by adding an amplified experiential feel to the written discourse as well as evoking the combination of cultural and spatial morphologies (e.g. "Cathedral" and "Coast"), which implies an effort by the tour operator to decipher and construe an intelligible "framework or mental grid through which the traveler will filter his perceptions while abroad" (Adams, 1984, p. 472).

The list of key words projected in the perceptual map displays recurring relations already evidenced in previous cases, referring primarily to levels of spatial correlations, which are visible, for example in the proximity of "Lisbon", "Sintra", "Cascais" and "Estoril", indicating a geographical convergence that could be influenced by Lisbon's cultural density and functional competence, acting as a gateway to finer levels of territorial immersion. This spatial configuration suggests once again a huband-spoke model.

In the vicinity of the concept of "Heritage" are represented nodes awarded with the UNESCO distinction, "Évora" and "Porto", but also a cultural configuration evoked by the word "Castle". While this association appears to be straightforward it also suggests a biased conceptualization of space due to the presence of other UNESCO classified sites in the perceptual map. 


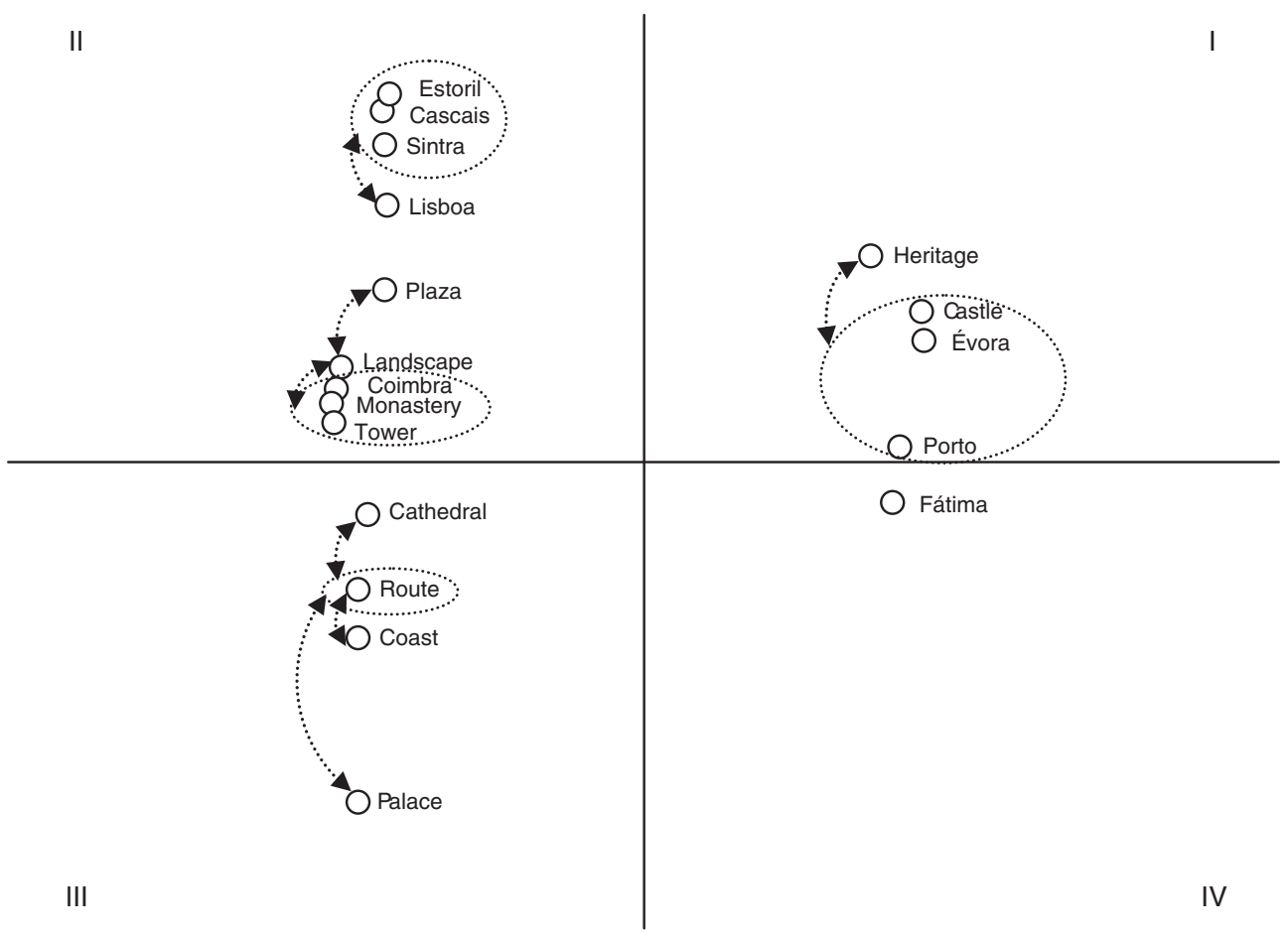

Fig. 5. Semantic model of Spanish programming.

Quadrant IV is defined exclusively by the word/concept "Fátima", which again suggests this node's idiosyncratic and individual relevance embodying the Portuguese religious centre and destination.

\subsection{The Italian mental model}

The list of unique words exhibits Lisbon's predominance, clearly demarcated from the second most cited word, "Porto" (Table 7). This gap exposes Lisbon's motivational dominance in the tour operators' written discourse, asserting itself as a critical driver when conceptualizing Portugal as a tourist destination. Also, it exerts an important functional mission as acknowledged in previous models.

"Fátima" is the third most cited word, which conveys the significance of religious themes for Italian tour operators. In all, 11 key words identify spatial units, suggesting the prominence of spatial referents when conceptualizing place, despite the high concentration of

Table 7

Output frequencies - Italian programming.

\begin{tabular}{lll}
\hline \multicolumn{2}{l}{ Descending frequency list } & \\
\hline Word & Freq & Pcnt \\
\hline LISBON & 819 & 23,9 \\
PORTO & 337 & 9,9 \\
FÁTIMA & 328 & 9,6 \\
COIMBRA & 264 & 7,7 \\
BRAGA & 192 & 5,6 \\
ÓBIDOS & 168 & 4,9 \\
BATALHA & 157 & 4,6 \\
MONASTERY & 150 & 4,4 \\
SINTRA & 120 & 3,5 \\
CATHEDRAL & 118 & 3,5 \\
CAR & 112 & 3,3 \\
SANCTUARY & 110 & 3,2 \\
ÉVORA & 99 & 2,9 \\
CASTLE & 98 & 2,9 \\
GUIMARÃES & 92 & 2,7 \\
PALACE & 90 & 2,6 \\
TOMAR & 83 & 2,4 \\
VILLAGIO & 83 & 2,4 \\
\hline
\end{tabular}

frequencies around "Lisbon". This may be correlated with the latent programming prototype evoked by the word "Car" in association with "Lisbon", which implies circulation models that intercept and connect other geographical nodes. Additionally, "Porto" also seems to assume a portal purpose, by enabling access to secondary nodes (e.g. "Braga”).

Furthermore, the conceptual map (Fig. 6) exhibits particular spatial associations which are compatible to circulation corridors (e.g. "Sintra"-[“óbidos”-“Batalha”]-“Fátima”-“Tomar”; “Coimbra”-“Évora”) that suggest “cumulative attraction” (Lue, Crompton, \& Fesenmaier, 1993, p. 297) patterns that bring up "complementary opportunities" (Guedes \& Jiménez, 2015, p. 108).

In addition, the conceptual map (Fig. 6) seems to validate associations between specific geographical units and particular architectural morphologies, exemplified through specific word relationships: "Monastery" and "Batalha", evoking the "Batalha Monastery," a UNESCO classified property; "Braga" and "Sanctuary", suggesting the "Bom Jesus do Monte" sanctuary, an important Portuguese religious monument; "Braga" and "Cathedral", indicating the "Sé de Braga", a National Monument; and "Porto" and "Palace", suggesting the "Palácio da Bolsa", classified National Monument and former stock exchange.

Quadrant IV is defined by the single word "Guimarães" (town), suggesting that Italian tour operators' ascribe a distinctive character to this node. This could be a result of the tour operators' perception of the importance of Guimarães as the cradle of the Portuguese national identity, which is often read in the tour operators' narratives, as well as its UNESCO classification. Although this town is also known for its "Castle", the perceptual map does not display this element in the same quadrant as the word "Guimarães". This could be due to its crosswise spatial association, namely to "Lisbon", "Óbidos" and "Tomar" who also possess important castles. Additionally, Quadrant I, which includes the word "Castle", also contains the word "Villaggio", 5 evoking specific low density contexts and small urban morphologies not shown in the perceptual map (e.g. Ponte de Lima, Ponte da Barca).

\footnotetext{
${ }^{5}$ Kept the original word due to its association with small towns.
} 


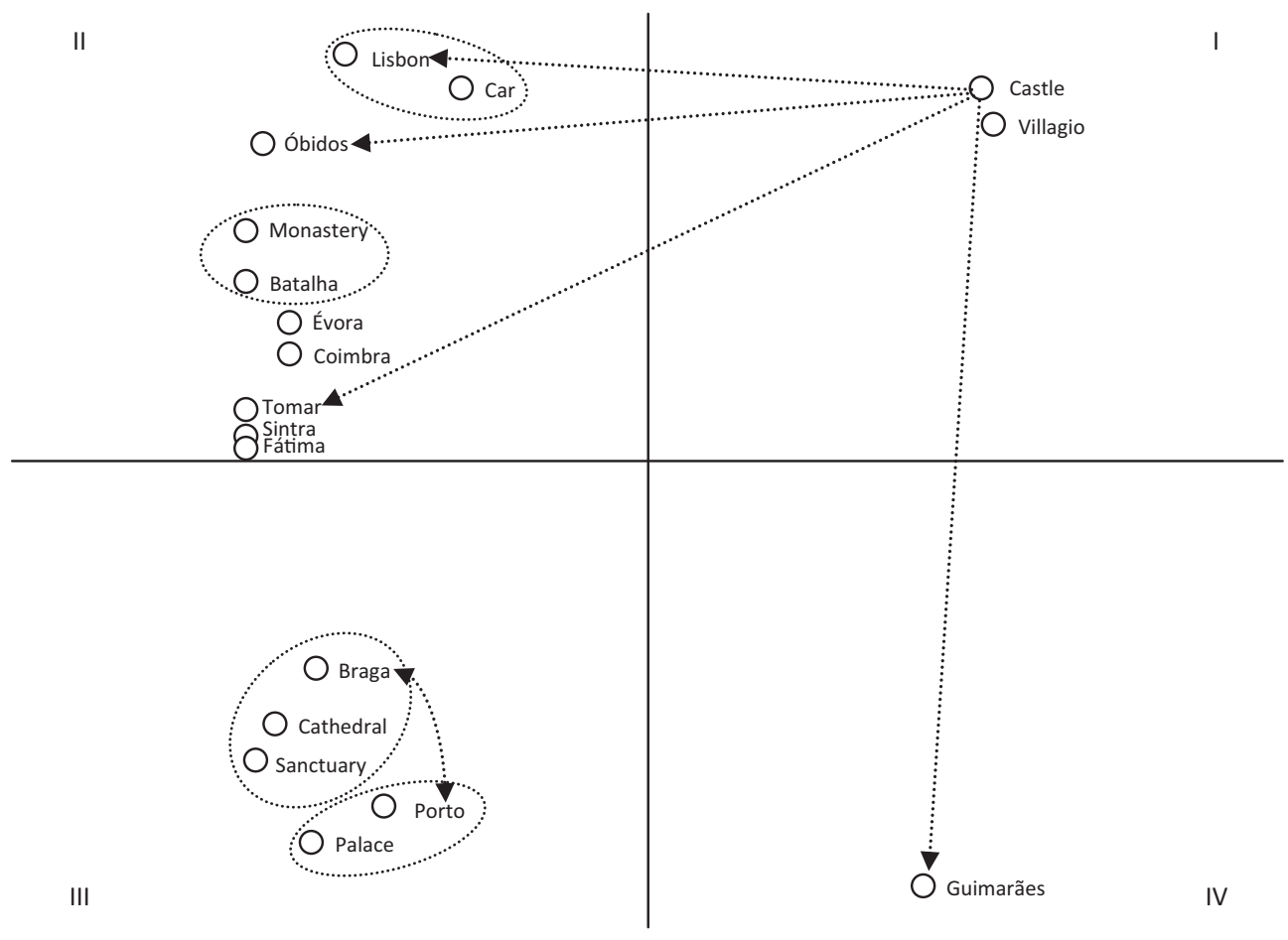

Fig. 6. Semantic model of Italian programming.

\subsection{The Dutch mental model}

"Lisbon" and "Porto" emerge as the top key words in the Dutch semantic model (Table 8), confirming that these two spatial units have a centripetal impact as a result of the convergence of inbound tourism movements, which is common to all package tours' discourses, as well as a centrifugal effect due to their functional capacity to interconnect with other spatial units within the destination.

The third most frequently mentioned word evokes a regional platform, "Alentejo", a geographical circumscription inducing again the concept of natural area, as well as the 5th most frequent word "Douro". This last word/concept exhibits a close relation to "Porto", suggesting an historical bond between the wine-growing region and the city ("Porto") where the wine was stored and shipped, accrediting the name Port wine (the city's name). The evoked cultural and historical frame is confirmed in the semantic model (Fig. 7) through the clustering of the word "Wine" (e.g. Port wine). Furthermore, the concept of "Landscape" (in connection with the word "Car") evokes gaze and contemplation, also suggesting a metaphor for cultural heritage, which might reasonably be associated with the Douro terroir due to its historical significance and UNESCO classification.

Supplementary elements, i.e. "River" and "Valley", which picture the destination, could be extrapolated as concepts that characterize and densify the "Douro" scenery, despite being located in a different quadrant, but likewise apply to other spatial referents (e.g. "River" and "Lisbon").

As recognized in previous mental models (e.g. Spanish model), the Dutch tour operator's discourse articulates the word/concept "Route" which evokes a structural and organizational meaning and purpose that coheres spatial units and resources. This word seems to interrelate with the word "Coast", an evocation of two concomitant meanings, i.e. a geographical setting and a cultural and historical allusion (e.g. the Portuguese discoveries).

Additionally, the word "Car" reinforces an archetype of tourist experience which refers to a more spontaneous and autonomous circulation within the destination which fosters territorial immersion, namely into the "Douro" "Landscape".

Furthermore, the words "Castle" and "Monastery" stand out, evoking different architectural morphologies which construe the destination's cultural heritage and convey a graphic and subjective portrayal of the destination.

The Dutch semantic model, as previous representations, tends to develop a prototype that is based on morphological recognition linked to spatial referents, a relationship that exhibits a particular emphasis of the tour operators' narrative. This can be illustrated through the confederation of concepts such as "Douro-Wine-Landscape".

The overlapping of spatial elements seems to be exerted in the Dutch written discourse, e.g. "Porto-Douro", embodying spatial corridors with a cultural and historical structure or frame. Also noticeable seems to be a particular spatial cluster, i.e. “Lamego-Coimbra-Sintra”, which outlines a

Table 8

Output frequencies - Dutch programming.

\begin{tabular}{lll}
\hline Descending frequency list & & \\
\hline Word & Freq & Pcnt \\
\hline LISBON & 80 & 18,3 \\
PORTO & 72 & 16,4 \\
ALENTEJO & 26 & 5,9 \\
RIVER & 26 & 5,9 \\
DOURO & 24 & 5,5 \\
CAR & 22 & 5,0 \\
ÉVORA & 21 & 4,8 \\
COIMBRA & 20 & 4,6 \\
ROUTE & 20 & 4,6 \\
WINE & 19 & 4,3 \\
CASTLE & 17 & 3,9 \\
COAST & 14 & 3,2 \\
LANDSCAPE & 14 & 3,2 \\
VALLEY & 14 & 3,2 \\
LAMEGO & 13 & 3,0 \\
MONSARAZ & 12 & 2,7 \\
MONASTERY & 12 & 2,7 \\
SINTRA & 12 & 2,7 \\
\hline
\end{tabular}




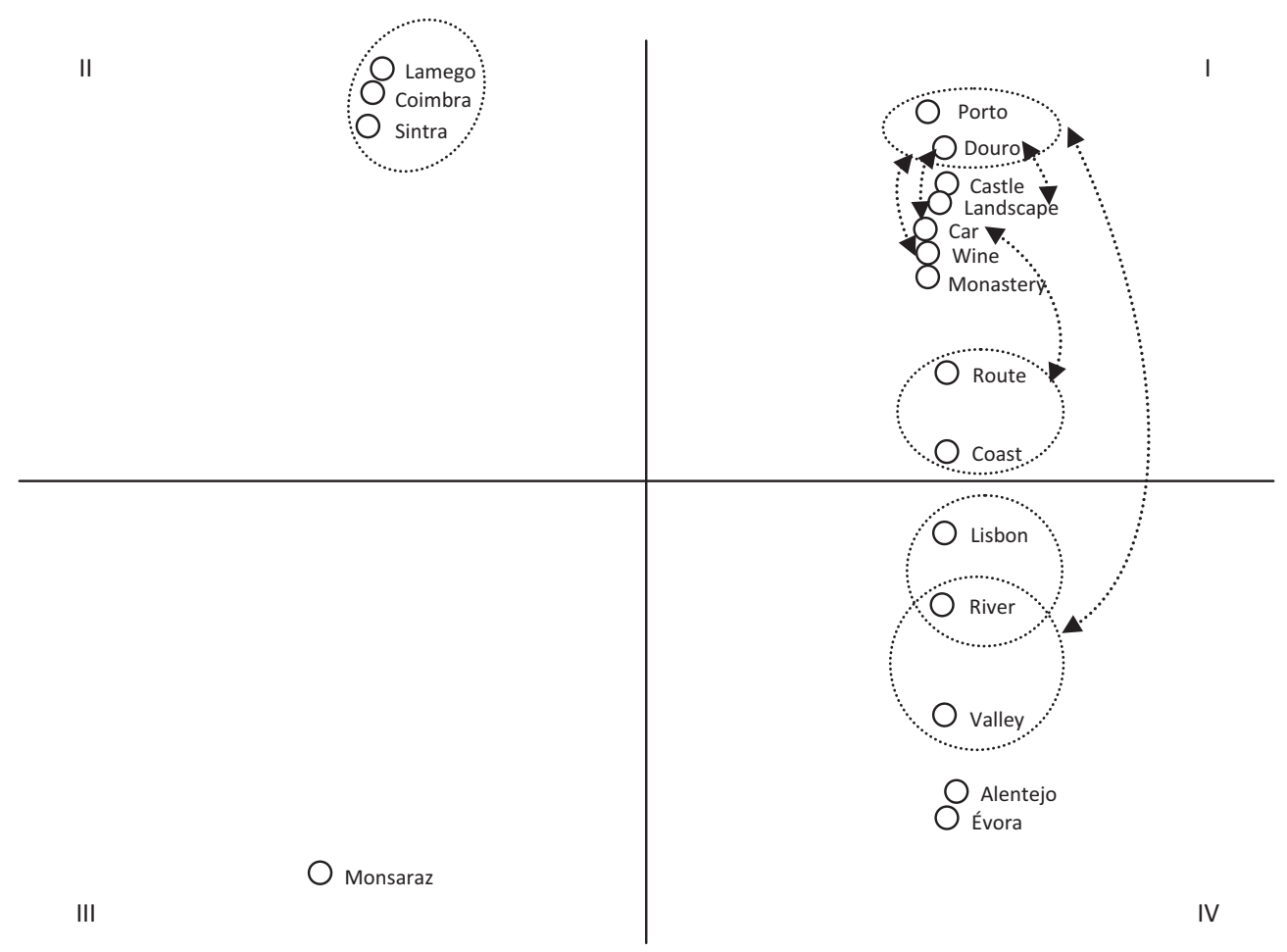

Fig. 7. Semantic model of Dutch programming.

profuse vertical corridor that intersects the Douro valley ("Lamego"), the central part of Portugal ("Coimbra") and an important cultural heritage node located on the outskirts of Lisbon ("Sintra"), which expands the territorial tourist experience.

Moreover, the Dutch perceptual map exhibits particular circumstances wherein the municipality unit stands out of its regional setting and boundary, an occurrence that is observed between the words "Alentejo" (region) and "Évora" (municipality), exposing this node's independent conceptual dimension that could be explained by its UNESCO endowment. Additionally, Quadrant III is defined exclusively by the spatial feature "Monsaraz", which is located in the Alentejo region, evoking its singular dimension and regional deviation. This suggests its valuable importance within the tour operators' discourse, which frequently depict this place as an idyllic medieval town with a view to the Guadiana (river) valley, suggesting its distinctive location near the Alqueva reservoir that is an emergent tourist pole in mainland Portugal.

\subsection{Synthesis}

Tour operator's written discourse shows that knowledge representation of mainland Portugal by different user groups, namely tour operators coming from distinct inbound markets, seems to be sustained by a nucleus of common semantic elements particularly in the field of spatial referents. "Lisbon" and "Porto" monopolize tour operators' narratives, being empowered by their cultural resources which act as "generators of tourism" as well as regulators of "tourism spatial patterns by influencing choice” (Guedes \& Jiménez, 2015, p. 107). These nodes exhibit a centripetal impact validated by the convergence of the written discourse of all tour operators as well as a centrifugal influence due to their functional capacity to interconnect with other spatialities in the destination.

The analysis exhibits clusters of spatial nodes and cultural and thematic features that bestow context and texture to the tourist experience (e.g. "Braga”-“Coimbra”-"Baroque”; "Porto"-“Palace”-“Medieval”; "Algarve"-“Beach"-“Coast”; “Douro"-“Valley"-“Port”-“Wine”). In many occasions the aforementioned articulation can be extracted through complementary reading of the textual content, exemplified by the following features: "Coimbra" with an academic symbolism concomitant to its University legacy and "Fátima", whose endogenous content has a univocal nature based on its religious domain. The analysis also uncovers other cultural markers that are reiterated in different semantic models, which are based on a set of architectural morphologies that exhibit a figurative and idiosyncratic dimension (e.g. "Castle", "Monastery", "Cathedral" and "Azulejos").

Furthermore, this research displays spatial recurrences that have a "circular outline" seemingly "federating geographical units that are linked by corridors" (Guedes \& Jiménez, 2015, p. 114) which could be interpreted as "cumulative attraction" patterns (Lue et al., 1993, p. 297): "Lisbon-Sintra-Estoril-Cascais-Lisbon", "Lisbon-Sintra-ÓbidosBatalha-Fátima-Tomar-Coimbra-Évora-Lisbon” or "Porto-Braga-Porto". Additional semantic spatial combinations can be observed along vertical and horizontal corridors that amplify the tourist experience and territorial immersion illustrated, respectively, by the sequences: "Sintra-Coimbra-Lamego" and "Porto-Douro/Régua".

This study also reveals particular semantic representations wherein the municipality unit ("Évora") and its respective regional frame ("Alentejo") are autonomous, which stems from the independent conceptual dimension that specific municipalities attain in limited contexts.

Moreover, the tour operators' narrative seems to depend in many circumstances on regional frames ("Douro", "Alentejo" and "Algarve”) that evoke the concept of natural area endowed by physical distinctiveness and a particular set of cultural characteristics that suggest thematic subjects that withhold experiential opportunities.

The written discourse also exhibits particular lexicon that evoke experiential archetypes that tend to include activities (e.g. cruises evoked by the word "Cruise" or train tours evoked by the word "Train"), as well as subjective features that give a full sense of the tourist experience by adjoining spatial units and resources (e.g. "Tour" and "Route") and additionally suggesting a contemplative experience (gaze).

Based on the question "What is the meaning of the text?" (Carley \& Palmquist, 1992, p. 607) and semantic substrate uncovered from each of the previous semantic models, which exhibit a fairly common 
understanding and interpretation of mainland Portugal, we venture a prototype of shared mental model (Fig. 8). This proposal is based on phenomenological approach which "invites us to explore some of the unifying conditions and forces in the human experience of world" (Buttimer, 1976, p. 280), and thus enables us to extrapolate a "shared horizon” (Buttimer, 1976, p. 281) from individual constructs. Responses to "what" is seen by the subject (tour operator) but also the "way" it is perceived can thus converge into a general concept and understanding of mainland Portugal as destination through the tour operator's eyes.

\section{Conclusions}

Following the "spirit of phenomenological purpose" (Buttimer, 1976, p. 280), this research sought to capture the tour operator's intelligibility of mainland Portugal as a tourist destination by interpreting the written discourse of each one of the six most relevant inbound markets and construing a shared mental model that expresses a comprehensive articulation of new signifying structures and a common "sense of place" (Tuan, 1979, p. 410).

Cognitive mapping provided valid information about the conceptual framework, meaning and perception that tour operators have about the destination, which is conveyed through the brochures' written text. This analysis allowed to understand their conceptual and declarative knowledge, which exhibits certain specificities according to each inbound market but also uncovered a common denominator of "shared knowledge" (Carley \& Palmquist, 1992, p. 605). This suggests that "commercial interests and informational roles mix under the postmodern 'regime of signification"' (Santos, 2004, p. 134), which globalization amplified by allowing "flat standardized notions of destinations" (Santos, 2004, p. 123). Observed lexical reiterations (e.g. "Lisbon" and "Porto") across all tour operators' discourses seemingly imply that "representations of identities, destinations, and interactions are embedded with dominant ideological constructs" (Santos, 2004, p. 134).

Nonetheless, it is clear that the conceptualization of Portugal as a tourist destination exhibits greater signaling by increasing the diversity of markers that point to new nodes and places, different from the monolithic and highly concentrated paradigm that fostered Portuguese tourism development since the 1960s around the Algarve.

Thus, this study suggests that a new "language of tourism" (Dann, 1996, p. 2) is being articulated and transferred to society (main inbound markets) through a network of concepts (Carley \& Palmquist, 1992, p. 602) that bring to fruition a new prototype of mainland Portugal which indeed asserts and increases otherness through a wider set of "signifying structures that mark" (Culler, 1990, p. 10) the destination.

Understanding and knowledge that tour operators exert on mainland Portugal has expanded but concurrently it cannot be dissociated from globalization and the "collapse of spatial barriers" (Harvey, 1989, p. 293) which encourages interdependence of people and countries (Aramberri, 2009, p. 368). That seems to explain various identical semantic reiterations between inbound markets which we do not interpret as a reduction of otherness but as a side effect of globalization

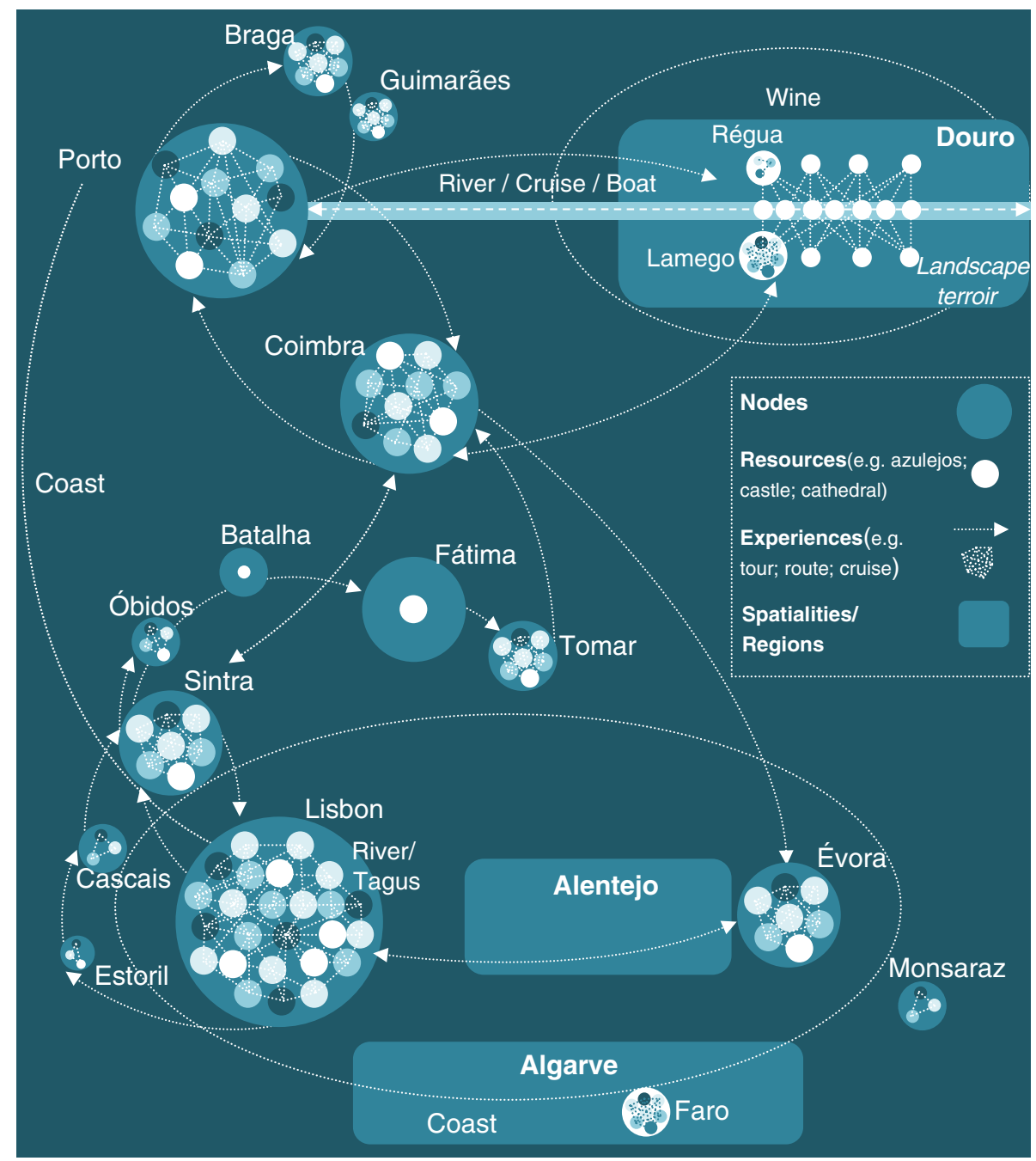

Fig. 8. Schematic illustration of a shared mental model. 
which tends to "camouflage notions of nationalism, fragmentation, and differentiation" (Santos, 2004, p. 134).

Despite the overlapping articulations of meaning and interpretation the tour operator's discourse exhibits a richer semantic structure, and a fuller image of mainland Portugal as a destination, which illustrates Harvey's assertion that as "spatial barriers diminish so we become much more sensitized to what the world's spaces contain" (1989, p. 294). Hence, "the collapse of spatial barriers does not mean that the significance of space is diminishing" (1989, p. 293) but can serve as an encouragement for tour operator's (capital withholders) "to exploit minute spatial differentiations to good effect” (1989, p. 294).

A synthesis of all tour operator's mental models can thus articulate and convey what Tuan (1979) identified as the "sense of place" which results from a "moral and aesthetic discernment to sites and locations" (Tuan, 1979, p. 410) by human beings and in our case, the tour operator's judgment and sensitivity of mainland Portugal as a tourist destination. Also, the fully awareness of place is conceivable when one can "see it as a whole from a distance" and thus acquire the stable existence of place which is "independent of the perceiver" (Tuan, 1979, p. 411). This is what this study purports - a common "sense of place" (Tuan, 1979, p. 411) which is more than the sum of all mental models.

Therefore, the written content of travel brochures unveils the implication of places (e.g. "monuments, artworks, buildings and cities") as organizers of space "into centres of meaning" (Tuan, 1979, p. 415) and their capacity to condense and affect the tour operator's interpretation and conceptualization of the destination. The "overpowering feature in the landscape creates its own world, which may expand or contract with the passing moods of the people, but which never completely loses its identity." (Tuan, 1979, p. 416). This explains the convergence of different tour operator's discourse towards an analogous interpretation of the destination due to the immanent effect of some "symbols that transcend the bounds of a particular culture" (Tuan, 1979, p. 416) which globalization amplifies. Consequently, it reveals opportunities for Portugal to develop its image as an international tourist destination based on a richer semantic network that supports tourism polarization and thus responds to a wider public spectrum.

Although this research holds "inherent limitations" due to its exploratory character, which "relies on subjective judgments to some extent" (Choi et al., 2007, p. 128), it provides knowledge on "how" tour operators perceive mainland Portugal as a tourist destination, what might encourage further research that measures the level of effectiveness of destination marketing and positioning strategies and programs managed by Portuguese destination marketing organizations (DMO), considered to be "the main vehicle to compete and attract visitors to their distinctive place or visitor space" (Pike \& Page, 2014, p. 202).

Thus, some practical managerial implications for Portugal's international tourism development and marketing can be drawn from this research. Since tour operator's textual content resonates constant images across all inbound markets and equally seems to point to new nodes and places, Portuguese DMOs could perfect and increase their capacity to manage marketing campaigns by synchronizing efforts with tour operators in different inbound markets. This approach could allow to further amplify results and achieve a sustainable tourism by broadening the spectrum of tourism typologies "rather than the equivalent of a single, dominant type of tourism" (Carey, Gountas, \& Gilbert, 1997, p. 431). Likewise, such effort could enhance levels of satisfaction of particular niche markets and concurrently magnify the spatial and economic impacts of tourism. Providing more information and deeper knowledge of Portugal (e.g. namely on cultural and natural resources) DMOs could induce tour operators to extend programming to more peripheral areas as well as plan holiday packages within a medium and long term which could impact positively on the destination by reducing the risk of uncertainty for local suppliers.

Therefore, this research exhibits the pertinence of textual content analysis of travel brochures as a managerial tool that can further elicit correlational relationships between DMOs and "induced agents"
(Gartner, 1993, p. 208). This link can further evolve to an open system methodology, as recommended by Xiang, Kothari, Hu, and Fesenmaier (2007), that "enables managers to see interrelationships" (Xiang et al., 2007, p. 88), and thus encourage networking capability of a DMO and ultimately improving the destination's success (Volgger \& Pechlaner, 2014).

Furthermore, DMOs have increasingly been moving into branding and marketing strategies as a result of growing international competition as well as in the effort to attain positional advantages (differentiation) (Pike \& Page, 2014; Zavattaro, Daspit, \& Adams, 2015). This attempt involves data collection and analysis, that can be achieved through systematical study of textual content, namely of tour operators' holiday brochures which should be followed by supplementary assessment of the consumer's perception of the destination's image, which plays (along with quality) "the most important role in tourists' evaluation of a destination” (Gartner \& Ruzzier, 2011, p. 471).

From an academic perspective, the general conceptual challenge of this paper commences with the discussion of phenomenology and the importance of discourse, which articulates meaning and intelligibility (Heidegger, 1962), and extends the theoretical construct towards the purpose of this research, i.e. to provide an insight into the tour operator's conceptual knowledge of Portugal as a tourist destination through the textual content of travel brochures. Hence, phenomenology is used as "methodological conception" (Heidegger, 1962, p. 50) and theoretical justification which according to Pernecky and Jamal (2010) as received scarce attention from studies that use the term phenomenology but "neither elaborate on the philosophy of phenomenology, nor show theoretical application to (applied) research" (p. 1057). Therefore, this study underlines the importance of phenomenology by raising "questions pertinent to knowledge production and existential being" (Pernecky \& Jamal, 2010, p. 1072) through the tour operator's written discourse.

As such, the fundamental implication of this study is the construction of "consensual realities for policy making" (Ryan, 2000, p. 129) through applied phenomenology and acquire a common ground where tour operators and DMOs can harmonize destination marketing efforts and allow a sustainable approach towards tourism development.

\section{Acknowledgements}

The authors wish to thank Professor João Fernandes Rebelo and Professor Jan Mansvelt Beck for all their insightful help and comments on this paper.

\section{References}

Adams, K. (1984). Come to Tana Toraja, "land of heavenly kings": Travel agents and brokers in ethnicity. Annals of Tourism Research, 11, 469-485.

Aramberri, J. (2009). The future of tourism and globalization: Some critical remarks. Futures, 41(6), 367-376.

Brentano, F. (1995). Psychology from an empirical standpoint. (A. Rancurello, D. Terrell \& L. McAlister, Trans.). New York: Routledge. (Original work published 1874)

Buttimer, A. (1976). Grasping the dynamism of lifeworld. Annals of the Association of American Geographers, 66(2), 277-292.

Carey, S., Gountas, Y., \& Gilbert, D. (1997). Tour operators and destination sustainability. Tourism Management, 18(7), 425-431.

Carley, K., \& Palmquist, M. (1992). Extracting, representing, and analyzing mental models. Social Forces, 70(3), 601-636

Choi, S., Lehto, X., \& Morrison, A. (2007). Destination image representation on the web: Content analysis of Macau travel related websites. Tourism Management, 28(1), 118-129.

Croft, W., \& Cruse, D. (2004). Cognitive linguistics. Cambridge: Cambridge University Press. Culler, J. (1981). Semiotics of tourism. The American Journal of Semiotics, 1(1/2), 127-140. Culler, J. (1990). Framing the sign: Criticism and its institutions. University of Oklahoma Press.

Dann, G. (1996). The language of tourism: A sociolinguistic perspective. Oxford: CAB International.

Ellis, J., \& Cohen, G. (2008). Memory for intentions, actions and plans. In G. Cohen, \& A Conway (Eds.), Memory in the real world (pp. 141-172). East Sussex: Psychology Press.

Fillmore, C. (1976). Frame semantics and the nature of language. Annals of the New York Academy of Sciences, 280(1), 20-32. 
Fillmore, C., \& Baker, C. (2009). A frames approach to semantic analysis. In B. Heine, \& H. Narrog (Eds.), The Oxford handbook of linguistic analysis (pp. 313-886). Oxford: Oxford University Press.

Foucault, M. (1980). Truth and power. In C. Gordon (Ed.), Power/Knowledge: Selected interviews and other writings (1972-1977) (pp. 109-133). New York: Pantheon Books.

Gartner, W. (1993). Image formation process. Journal of Travel \& Tourism Marketing, 2, $191-216$.

Gartner, W., \& Ruzzier, M. (2011). Tourism destination brand equity dimensions: Renewal versus repeat market. Journal of Travel Research, 50(5), 471-481.

Goodall, B. (1990). How tourists choose their holidays: An analytical framework. In B. Goodall, \& G. Ashworth (Eds.), Marketing in the tourism industry: The promotion of destination regions (pp. 1-17). London: Routledge.

Govers, R., Go, F., \& Kumar, K. (2007). Virtual destination image: A new measurement approach. Annals of Tourism Research, 34(4), 977-997.

Guedes, A., \& Jiménez, M. (2015). Spatial patterns of cultural tourism in Portugal. Tourism Management Perspectives, 16, 107-115.

Harvey, D. (1989). The condition of postmodernity: An enquiry into the origins of cultural change. Cambridge MA \& Oxford UK: Blackwell.

Heidegger, M. (1962). Being and time (J. Macquarrie \& E. Robinson, Trans.). New York: Harper \& Row, Publishers, Incorporated. (Original work published 1927)

Hollinshead, K. (1999). Surveillance of the worlds of tourism: Foucault and the eye-ofpower. Tourism Management, 20, 7-23.

Husserl, E. (1983). Ideas pertaining to a pure phenomenology and to a phenomenological philosophy. First book. General introduction to a pure phenomenology. (F. Kersten, Trans.). The Hague: Martinus Nijhoff. (Original work published 1976)

Johnson-Laird, P. (1980). Mental models in cognitive science. Cognitive Science, 4, 71-115.

Johnson-Laird, P. (1983). Mental models: Towards a cognitive science of language, inference, and consciousness. Cambridge, MA: Harvard University Press.

Kärcher, K. (1996). Re-engineering the package holiday business. In S. Klein, B. Schmid, A. Tjoa, \& H. Werthner (Eds.), Information and communication technologies in tourism (pp. 221-234). Wien: Springer-Verlag.

Li, Y. (2000). Geographical consciousness and tourism experience. Annals of Tourism Research, 27(4), 863-883.

Lue, C., Crompton, J., \& Fesenmaier, D. (1993). Conceptualization of multi-destination pleasure trips. Annals of Tourism Research, 20, 289-301.

MacCannell, D. (1976). The tourist: A new theory of leisure class. Berkley: University of California Press.

Marshall, M. (1996). Sampling for qualitative research. Family Practice, 13(6), 522-525.

Martin Randall Travel (2013). 2014 \& October-December 2013. [Brochure]. London, UK: Martin Randall Travel Ltd.

Pan, B., \& Fesenmaier, D. (2006). Online information search: Vacation planning process. Annals of Tourism Research, 33(3), 809-832.

Pernecky, T., \& Jamal, T. (2010). (Hermeneutic) Phenomenology in tourism studies. Annals of Tourism Research, 37(4), 1055-1075.

Pike, S., \& Page, S. (2014). Destination marketing organizations and destination marketing: A narrative analysis of the literature. Tourism Management, 41, 202-227.

Richards, G. (1997). Cultural tourism in Europe. Wallingford, Oxon: Cab International.

Rodrigue, J., Comtois, C., \& Slack, B. (2006). The geography of transport systems. Oxon: Routledge.

Ryan, C. (2000). Tourist experiences, phenomenographic analysis, post-positivism and neural network software. The International Journal of Tourism Research, 2(2), 119-131.

Salim, M., Ibrahim, N., \& Hassan, H. (2012). Language for tourism: A review of literature. Procedia - Social and Behavioral Sciences, 66, 136-143.

Santos, C. (2004). Framing Portugal: Representational dynamics. Annals of Tourism Research, 31(1), 122-138.

Sharpley, R. (2002). The consumption of tourism. In R. Sharpley, \& D. Telfer (Eds.), Tourism development: Concepts and issues (pp. 300-318). Clevedon: Channel View Publications.
Smith, D. (2013). Phenomenology. In E. Zalta (Ed.), The Stanford encyclopedia of philosophy (Winter 2013 Edition ) (Retrieved November 6, 2015, from) http://plato.stanford. edu/entries/phenomenology/\#5

Solaz-Portolés, J., \& López, V. (2008). Tipos de conhecimento e suas relações com a resolução de problemas em ciências: Orientações para a prática. Sísifo, 6, 105-114

Stepchenkova, S., \& Morrison, A. (2006). The destination image of Russia: From the online induced perspective. Tourism Management, 27(5), 943-956.

Timms, D. (1971). The urban mosaic: Towards a theory of residential differentiation. Cambridge: Cambridge University Press.

Tuan, Y. -F. (1979). Space and place: Humanistic perspective. In S. Gale, \& G. Olsson (Eds.) Philosophy in geography (pp. 387-427). Dordrecht: D. Reidel.

Turner, L., \& Ash, J. (1975). The golden hordes: International tourism and the pleasure periphery. London: Constable.

Urry, J. (1990). The tourist gaze. London: Sage Publications.

van Dijk, T. (1985). Semantic discourse analysis. In T. van Dijk (Ed.), Handbook of Discourse Analysis: Dimensions of discourse. 2. (pp. 103-112). London: Academic Press.

Volgger, M., \& Pechlaner, H. (2014). Requirements for destination management organizations in destination governance: Understanding DMO success. Tourism Management, 41, 64-75.

Woelfel, J. (1998). User's guide Catpac II: version 2.0. Rah Press

Xiang, Z., Kothari, T., Hu, C., \& Fesenmaier, D. (2007). Benchmarking as a strategic tool for destination management organizations. Journal of Travel \&' Tourism Marketing, 22(1), 81-93.

Zavattaro, S., Daspit, J., \& Adams, F. (2015). Assessing managerial methods for evaluating place brand equity: A qualitative investigation. Tourism Management, 47, 11-21.

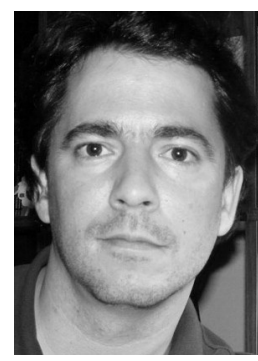

A. S. Guedes earned his Ph.D. in tourism from the University of Salamanca. He is currently working as a senior technician at North of Portugal DMO, and as a teacher at the University of Trás-os-Montes and Alto Douro. His area of research interest includes tourism geography, tourism planning, spatial analysis, cultural tourism, wine tourism, and river tourism.

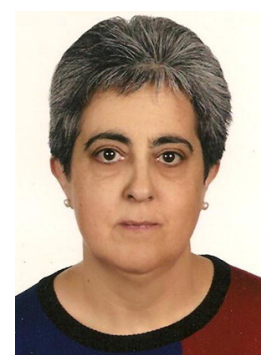

$\mathbf{M}^{\mathbf{a}}$ Isabel M. Jiménez earned her Ph.D. in geography at the University of Salamanca. She is currently working as a teacher at the University of Salamanca. Her area of research interests includes tourism geography, mountain tourism, new resources and sustainability in tourism. 